\title{
Mourn for Professor YU Shen
}

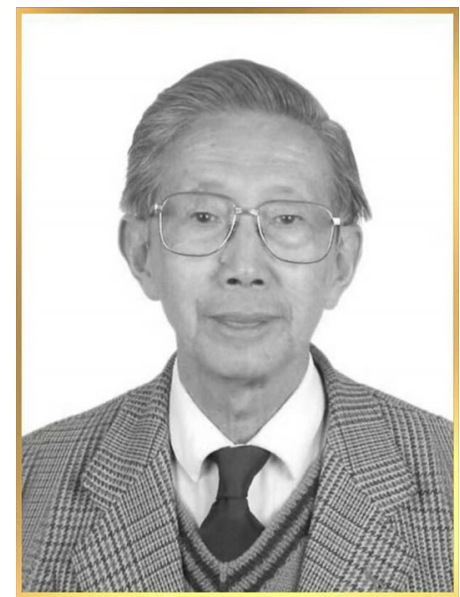

YU Shen

(1933-2021)
Dear colleagues and friends,

We are extremely sorry to notify that Prof. YU Shen, one of the founding editors of Journal of Thermal Science, also former Executive Chief Editor and Honorary Editor-in-Chief, passed away on 26th July, 2021, in Beijing, at the age of eighty-eight.

After two months of medical rescue in Peking Union Medical College Hospital and Beijing Longfu Hospital, Prof. YU died of pulmonary infection (bacterial pneumonia).

Prof. YU was born in 1933, graduated from Shanghai Jiao Tong University, entered in Institute of Engineering Thermophysics, Chinese Academy of Sciences, as a graduate in September 1963, and started to hold the post of the Executive Chief Editor of JTS in 1994.

As a scientist, Prof. YU began the studies on supersonic cascade wind tunnel in 1972. Between 1992 and 1997, he traveled to many famous national laboratories in different countries and exchanged the academic progress on this field. From 1990, he served as secretary general of the conferences and participated in organizing several international academic conferences. He kept in touch with quite a few international scientists and made sincere friends with them.

From 1994, Prof. YU entered the Journal of Thermal Science (JTS) as the Executive Chief Editor. He put all his enthusiasm and efforts in the journal since then. As you know, he set quite rigorous standards on the manuscripts both in writing and in academic quality. He felt sincerely happy when receiving high level manuscripts from all over the world, which indicated that the international impact of the journal had improved. He enjoyed and devoted to working for the journal for almost thirty years.

We respect him very much as he was a man of wisdom and credit. He was gentle, kind and honest. He was loved, respected and counted on by so many people. The dedication made by him contributed a lot to the journal. We will miss him forever.

We are extremely sorry for his death, express our sincerest bless for him and deepest sympathy to his family.

July 28, 2021 